\title{
Reproductive hormones profile of Iraqi Awassi ewes immunized against synthetic inhibin- $\alpha$ subunit or steroid-free bovine follicular fluid
}

\author{
S.S.A. Kafaji ${ }^{1}$, J.A.A. Al-Sa'aidi ${ }^{2 *}$ and K.K. Khudair ${ }^{3}$ \\ ${ }^{1}$ Reproductive Physiology, College of Agriculture, University of Kerbala, ${ }^{2}$ College of Veterinary Medicine, \\ University of Al-Qadisiyah, ${ }^{3}$ College of Veterinary Medicine, University of Baghdad, Iraq \\ "Corresponding Author: Email: jbr20042002@yahoo.com
}

(Received August 29, 2017; Accepted October 7, 2017)

\begin{abstract}
The current study was conducted to investigate the impacts of active and passive immunization against synthetic inhibin- $\alpha$ subunit and steroid-free bovine follicular fluid, respectively, on reproductive hormones profile out of breeding season in Iraqi Awassi ewes. Follicular fluid was aspired from mature bovine follicles, treated with activated charcoal, used for immunization of male rabbits, and obtaining of SFBFF antiserum. Forty non-pregnant Awassi ewes were allocated into 4 groups $(n=10$ each). At day 38 of experiment, ewes were treated with intra-vaginal sponge impregated with medroxyprogesterone acetate 60 $\mathrm{mg}$ for 12 days. Ewes were treated at 0, 28 and 50 days with 4, 2 and $2 \mathrm{ml}$ of normal saline (control; C-ve), 400, 200 and 200 $\mu \mathrm{g}$ of ovalbumine (C+ve), 400, 200 and $200 \mu \mathrm{g}$ of inhibin (SI group), and $4 \mathrm{ml}$ of normal saline at 0 day, and $4 \mathrm{ml}$ and $2 \mathrm{ml}$ of SFBFF antiserum, at 28 and 50 days, respectively (AI group). Blood samples were collected at 24 and 48 hours before and after sponge withdrawal for assessment of FSH, LH, inhibin-B, Activin-A, E2 and P4. Before sponge withdrawal, FSH level increased in SI ewes, whereas only after sponge withdrawal, FSH, LH, activin-A and E2 levels increased in SI and AI ewes. Opposite results were shown of inhibin-B level. In conclusion, active or passive immunization against inhibin in Awassi ewes could augment reproductive functions out of breeding season in Iraqi Awassi ewes.
\end{abstract}

Keywords: Active Immunization, Passive Immunization, Follicular Fluid, Superovulation, Ewes, Reproduction Available online at http://www.vetmedmosul.org/ijvs
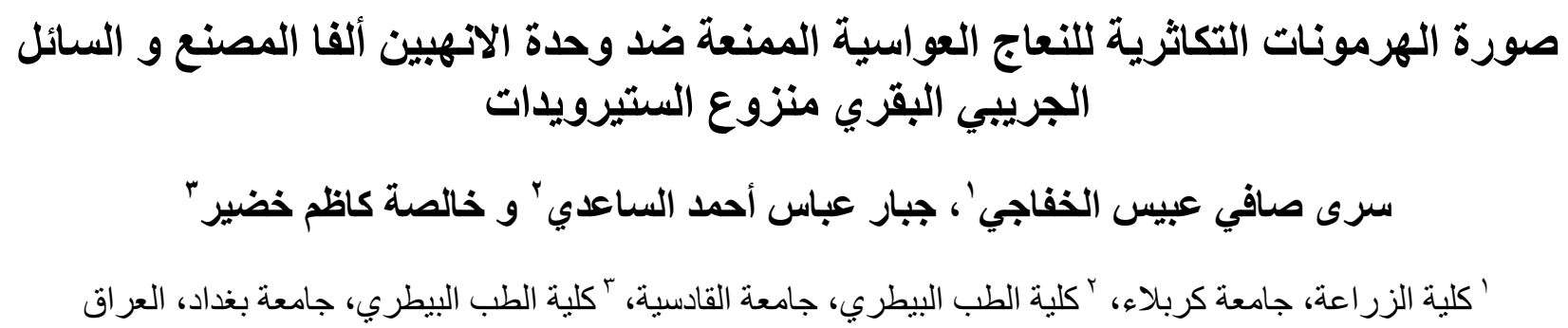

الخلاصة

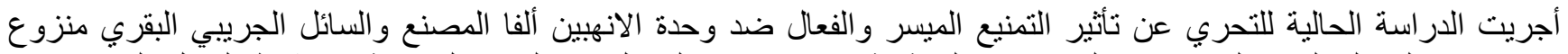

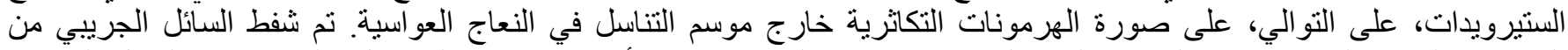

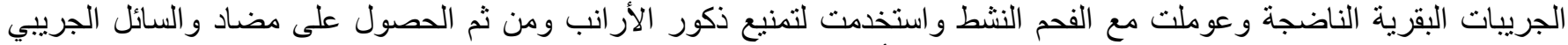

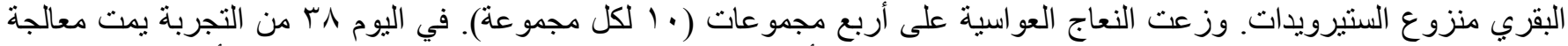

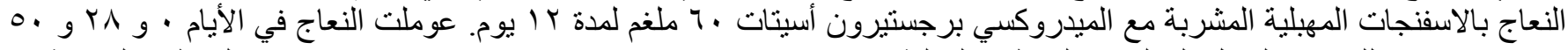

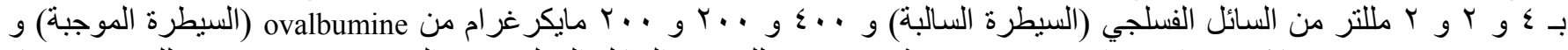

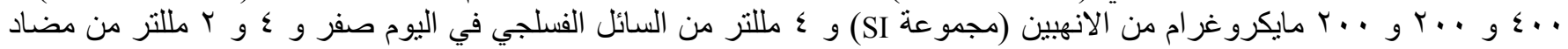

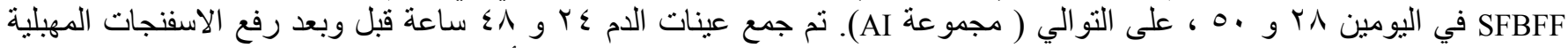

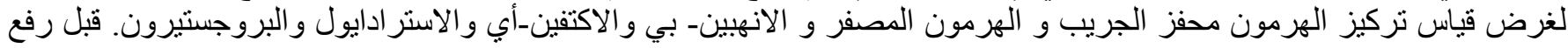




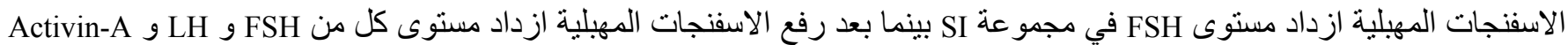

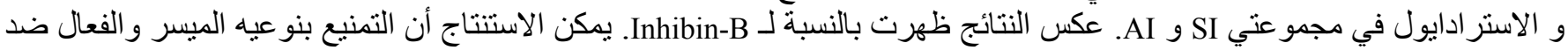
الانهبين في النعاج العو اسية يعزز من الوظائف التكاثرية خارج موسم التناسل.

\section{Introduction}

Awassi breed is a monotoccus with low ovulation rate and low incidence of twinning $(1,2)$. To increase fecundity in sheep, many non-genetic methods have been used, including administration of exogenous gonadotropins such as equine chorionic gonadotropin (3), passive and active immunization against ovarian steroids (4) and, recently, passive immunization against endogenous inhibin (5).

Superovulation has been encouraged successfully by passive immunization against alpha subunit of inhibin (69), and active immunization against synthetic inhibin (10). Improved reproductive action of mammals requires promotion of pituitary FSH secretion to authorize ovarian small follicles for development. In this circumstance, it is required to have surge of FSH secretion to augment follicular development to the point where $\mathrm{LH}$ receptors formed inside granulosa cells of the growing follicle. The key point for FSH surge is high levels of hypothalamic $\mathrm{GnRH}$ and pituitary activin, whereas the negative regulator is gonadal inhibins (11).

There are many attempts have been used to use for successfully to induce multiple ovulations, such as pig pituitary purified $\mathrm{FSH}$ and equine placenta purified equine chorionic gonadotropin; eCG. These products have been used as practical application in an embryo transfer program. The short half-life of FSH $(12,13)$ and long half-life of eCG and induction of endogenous anti-eCG antibodies (14) were the main side effects of these programs. So the regulatory effect of inhibin by way of passive or active immunization has been tested as an alternative method to increase FSH level and to induce ovarian follicular development in numerous species, including sheep $(15,16)$, cows $(17)$, goats $(18)$, mice $(7)$, and rats $(5,19)$.

The objective of current investigation was to evaluate the role of active and passive immunization against inhibin, as alternative methods, to improve ovulation rate and reproductive hormones profile during estrus cycle and gestation period in Iraqi Awassi ewes.

\section{Material and methods}

\section{Preparation of synthesis of inhibin}

Synthetic peptides $\left[\mathrm{NH}_{2}\right]$ with a Sequence chgleldrelvlakvralfldalghppvt [COOH], was obtained from Bio-synthesis Inc., USA, as $5 \mathrm{mg}$ of purified synthetic inhibin powder.

\section{Preparation of Steroid-free bovine follicular fluid (SFBFF)}

Bovine follicular fluid was aspired from bovine ovarian follicles $(\leq 15 \mathrm{~mm}$ in diameter) and centrifuged at $8000 \mathrm{rpm}$ for 15 minute at $4{ }^{\circ} \mathrm{C}$ to remove cellular debris. Activated charcoal $(10 \mathrm{mg} / \mathrm{ml})$ was added to the $\mathrm{FF}$, mixed for 1 hour at $4^{\circ} \mathrm{C}$ and centrifuged at $14000 \mathrm{rpm}$ for 90 minute at $4^{\circ} \mathrm{C}$ to remove charcoal with steroid to obtain steroid-free BFF. SFBFF was kept at $-20^{\circ} \mathrm{C}$ until use (19).

\section{Preparation of SFBFF antiserum}

Ten mature male rabbits have been injected for 5 times with $1 \mathrm{ml}$ of SFBFF subcutaneously (sc.) one week interval. One month after the last injection, blood was collected, centrifuged and antiserum was obtained and kept at $-20 \mathrm{C}^{\circ}$ until use(19).

\section{Animals}

Awassi ewes aged 2.5-3.5 years and weighed $50-58 \mathrm{~kg}$ were used in the present experiment. The animals were housed at night, while, freely feeding grass throughout the remaining hours of the day. Indoors, the ewes were fed concentrated feed supplemented with vitamins and wheat straw, water and minerals were freely available.

\section{Experimental design}

Forty non-pregnant mature Awassi ewes were allocated into 4 groups $\left(10\right.$ each). At treated at $38^{\text {th }}$ day of experiment, Awassi ewes were treated with intra-vaginal sponge impregnated with medroxyprogesterone acetate (MPA) for 12 days. First group ewes were treated at $0,28^{\text {th }}$, and $50^{\text {th }}$ days of experimental periods with subcutaneous injections of 4, 2 and $2 \mathrm{ml}$ of normal saline and served as negative control group (C-ve). Second group ewes were treated at $0,28^{\text {th }}$, and $50^{\text {th }}$ day of experiment with sc injections of 400, 200 and $200 \mu$ l of ovalbumine and served as positive control group $(\mathrm{C}+\mathrm{ve})$. Third group ewes were treated at $0,28^{\text {th }}$, and $50^{\text {th }}$ day of experiment with $\mathrm{sc}$ injections of 400, 200 and $200 \mu$ l of synthetic inhibin and served as SI treated group (SI). Forth group ewes were treated at 0 day with sc injection of $4 \mathrm{ml}$ of normal saline, and $4 \mathrm{ml}$ and $2 \mathrm{ml}$ of SFBFF antiserum, at $28^{\text {th }}$, and $50^{\text {th }}$ day of experiment and served as SFBFF antiserum treated group (AI). Blood samples were collected in nonheparinized tubes every 24 hours, started at 48 hours before and lasted at 48 hours after sponge withdrawal. Blood sera were separated and kept at $-22{ }^{\circ} \mathrm{C}$ until hormonal assessment of FSH, LH, inhibin-B, Activin-A, E2 and progesterone concentrations, using ELISA technique 
depended on the manufacturer instructions (Wuhan Fine Biological Technology).

\section{Statistical Analysis}

Results were expressed as mean \pm standard deviation. Comparisons between groups and periods values were performed using two way analysis of variance (ANOVAII) and Newman- Keuls. Differences were considered to be significant at the level of $\mathrm{P}<0.05$ (20). Statistical analysis was carried out using the GraphPad Prism version-5 (GraphPad Software, Inc. California, USA).

\section{Results}

The results of the current study confirmed the potency of passive and active immunoneutralization against endogenous inhibin, in Awassi ewes out of season breeding, to enhance the surge of FSH secretion from pituitary gland and to elevate gonadal estradiol biosynthesis by follicular cells.

\section{FSH}

In active immunized (SI) group ewes, serum FSH concentration registered significant increase $(p<0.05)$ before $48 \mathrm{hrs}$ and $24 \mathrm{hrs}$ of sponges withdrawal compared with other groups ewes, which showed no significance difference $(p>0.05)$ between each other during these periods. After sponge withdrawal (after $24 \mathrm{hr}$ and $48 \mathrm{hr}$ ), the concentrations in SI and AI group ewes elevated significantly $(\mathrm{p}<0.05)$ than control $(\mathrm{C}$-ve and $\mathrm{C}+\mathrm{ve})$ group ewes. In comparison between periods for each group, FSH concentrations of all group ewes elevated significantly $(p<0.05)$ after sponge withdrawal, but the elevation in SI and AI group ewes reached 2 times more than that of control groups (figure 1).

\section{LH}

Serum LH concentrations revealed no significant $(\mathrm{p}>0.05)$ differences among experimental group ewes during the periods before sponge withdrawal (before $48 \mathrm{hr}$ and $24 \mathrm{hr}$ periods). After sponge withdrawal, the concentrations in SI and AI group showed significant $(p<0.05)$ elevation than both of control group ewes. In comparison between periods, all group ewes showed gradual significant $(p<0.05)$ elevation of serum LH concentrations along with the progress of experiment periods, but the elevation in immunized groups (SI and $\mathrm{AI}$ ) was significantly $(\mathrm{p}<0.5)$ higher than control groups (figure 2).

\section{Inhibin-B}

As illustrated in figure (3), inhibin-B concentration showed significant decrease $(\mathrm{p}<0.05)$ in SI group ewes, at both periods before sponge withdrawal, in comparison with other groups. At periods of sponge withdrawal, the concentrations of inhibin-B still significantly downregulated in SI group ewes, where that of AI group ewes also declined significantly $(\mathrm{p}<0.05)$ than control groups as well as SI group after $24 \mathrm{hr}$ period of sponge withdrawal, but it showed no significant ( $\mathrm{p}>0.05$ ) difference compared with SI group ewes after $48 \mathrm{hr}$ of sponge withdrawal. In comparison between periods, in SI group ewes, the concentrations remained insignificant $(p>0.05)$ at all experimental periods, whereas that of other groups declined gradually along with experimental progress.

\section{Activin-A}

Serum concentrations of activin-A in SI and AI group ewes reported significant $(p<0.05)$ higher levels than other experimental groups during all periods of the experiment, where they showed gradual elevation along with the progress of the experiment until $24 \mathrm{hr}$ after sponge withdrawal, then decreased after $48 \mathrm{hr}$ of sponge withdrawal. In AI group ewes, serum activin-A concentration was significantly $(\mathrm{p}<0.05)$ higher, at $24 \mathrm{hr}$ and $48 \mathrm{hr}$ after sponge withdrawal, than that of SI group ewes at the same periods (figure 4 ).

\section{Estradiol-17B (E2)}

The results of serum estradiol-17B concentrations clarified in figure (5), showed significant $(\mathrm{p}<0.05)$ elevation in SI group ewes followed by AI group ewes at $48 \mathrm{hr}$ and $24 \mathrm{hr}$ periods before sponge withdrawal, whereas that of control groups reported insignificant $(p>0.05)$ difference between each other. After $24 \mathrm{hr}$ and $48 \mathrm{hr}$ of sponge withdrawal, the concentrations of E2 in all groups ewes were significantly $(p<0.05)$ elevated, but still the concentrations of SI and AI group ewes were significantly $(p<0.05)$ higher than that of control.

\section{Progesterone}

The results demonstrated in figure (6) revealed no significant $(\mathrm{p}>0.05)$ difference between experimental groups at $48 \mathrm{hr}$ and $24 \mathrm{hr}$ before sponge withdrawal, but significant decline was shown in SI and AI group ewes at $24 \mathrm{hr}$ and $48 \mathrm{hr}$ after sponge withdrawal compared with control groups. In comparison between periods, all groups reported gradual decline with the progress of the experimental periods. 


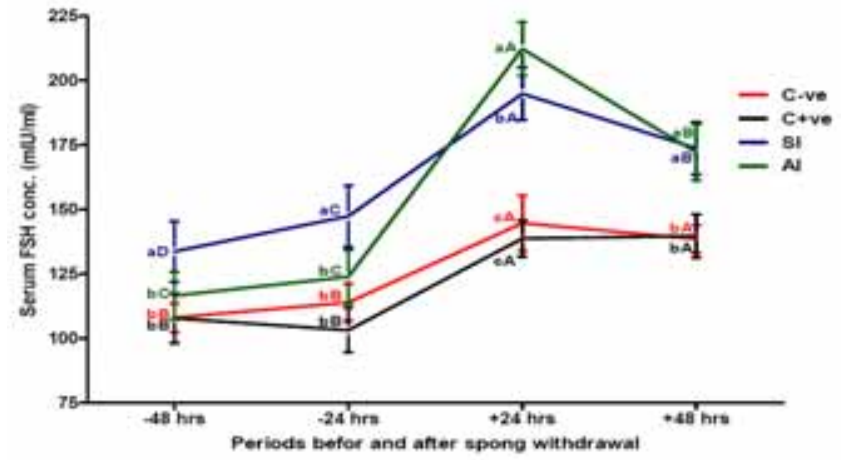

Figure 1: Serum FSH concentration $(\mathrm{mIU} / \mathrm{ml})$ before 48 and 24 hrs. (A and B) and after 24 and $48 \mathrm{hr}$. (C and D) sponge withdrawal at day 50 of treatment in Awassi ewes injected, at 0,28 , and 50 days of treatment, with 4, 2 and 2 $\mathrm{ml}$ of normal saline (control; C-ve), 400, 200 and $200 \mu \mathrm{g}$ of ovalbumine (positive control; C+ve), 400, 200 and $200 \mu \mathrm{g}$ of synthetic inhibin (SI group), and $4 \mathrm{ml}$ of normal saline followed by 4 and $2 \mathrm{ml}$ of SFBFF antiserum (AI group). The values represented as $\mathrm{M} \pm \mathrm{SD}$. Different small letters denote significant difference $(\mathrm{p}<0.05)$ between groups for each period. Different capital letters denote significant difference $(p<0.05)$ between periods for each group.

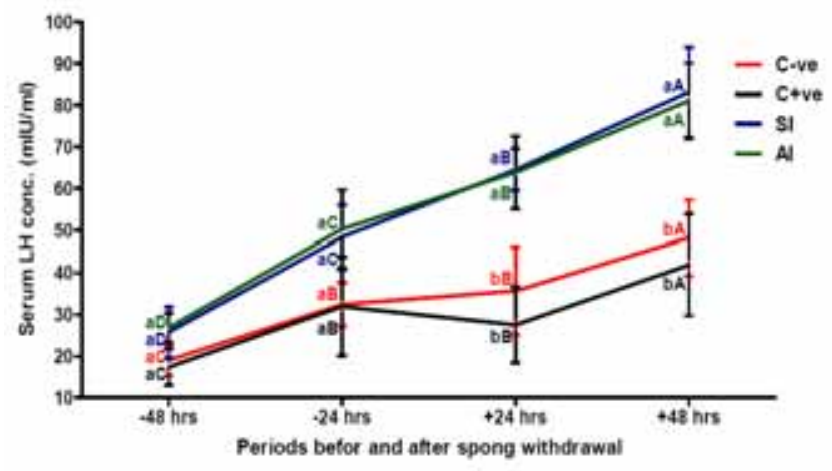

Figure 2: Serum LH concentration $(\mathrm{mIU} / \mathrm{ml})$ before 48 and 24 hrs. (A and B) and after 24 and $48 \mathrm{hr}$. (C and D) sponge withdrawal (at day 50 of treatment) in Awassi ewes injected, at 0,28, and 50 days of treatment, with 4, 2 and 2 $\mathrm{ml}$ of normal saline (control; C-ve), 400, 200 and $200 \mu \mathrm{g}$ of ovalbumine (positive control; C+ve), 400, 200 and $200 \mu \mathrm{g}$ of synthetic inhibin (SI group), and $4 \mathrm{ml}$ of normal saline followed by 4 and $2 \mathrm{ml}$ of SFBFF antiserum (AI group). The values represented as $\mathrm{M} \pm \mathrm{SD}$. Different small letters denote significant difference $(\mathrm{p}<0.05)$ between groups per each period. Different capital letters denote significant difference $(p<0.05)$ between periods per each group.

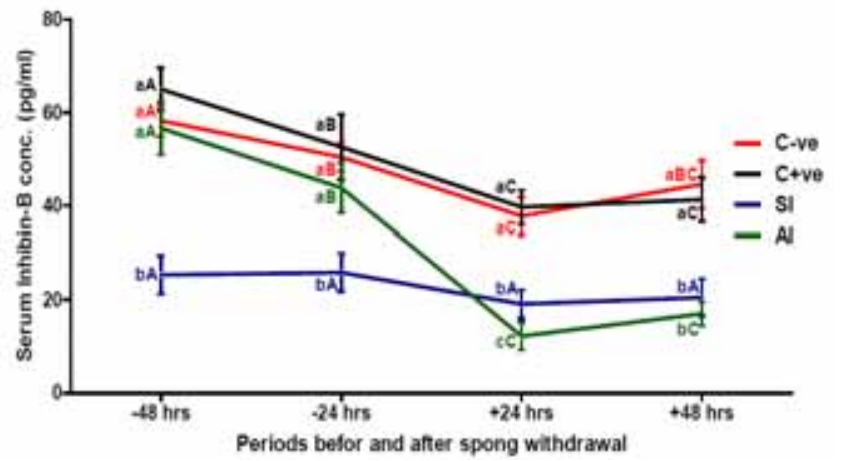

Figure 3: Serum Inhibin-B concentration $(\mathrm{pg} / \mathrm{ml})$ before 48 and 24 hrs.(A and B) and after 24 and $48 \mathrm{hr}$. (C and D) sponge withdrawal (at day 50 of treatment) in Awassi ewes injected, at 0,28, and 50 days of treatment, with 4, 2 and 2 $\mathrm{ml}$ of normal saline (control; C-ve), 400, 200 and $200 \mu \mathrm{g}$ of ovalbumine (positive control; C+ve), 400, 200 and $200 \mu \mathrm{g}$ of synthetic inhibin (SI group), and $4 \mathrm{ml}$ of normal saline followed by 4 and $2 \mathrm{ml}$ of SFBFF antiserum (AI group). The values represented as $\mathrm{M} \pm \mathrm{SD}$. Different small letters denote significant difference $(\mathrm{p}<0.05)$ between groups for each period. Different capital letters denote significant difference $(p<0.05)$ between periods for each group.

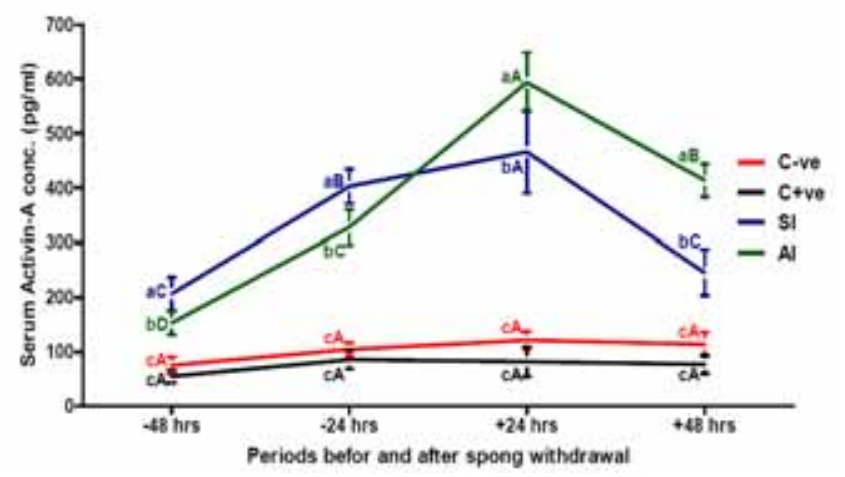

Figure 4: Serum Activin-A concentration $(\mathrm{pg} / \mathrm{ml})$ before 48 and 24 hrs.(A and B) and after 24 and $48 \mathrm{hr}$. (C and D) sponge withdrawal (at day 50 of treatment) in Awassi ewes injected, at 0,28 , and 50 days of treatment, 4,2 and $2 \mathrm{ml}$ of normal saline (control; C-ve), 400, 200 and $200 \mu \mathrm{g}$ of ovalbumine (positive control; C+ve), 400, 200 and $200 \mu \mathrm{g}$ of synthetic inhibin (SI group), and $4 \mathrm{ml}$ of normal saline followed by 4 and $2 \mathrm{ml}$ of SFBFF antiserum (AI group). The values represented as $\mathrm{M} \pm \mathrm{SD}$. Different small letters denote significant difference $(\mathrm{p}<0.05)$ between groups for each period. Different capital letters denote significant difference $(p<0.05)$ between periods for each group. 


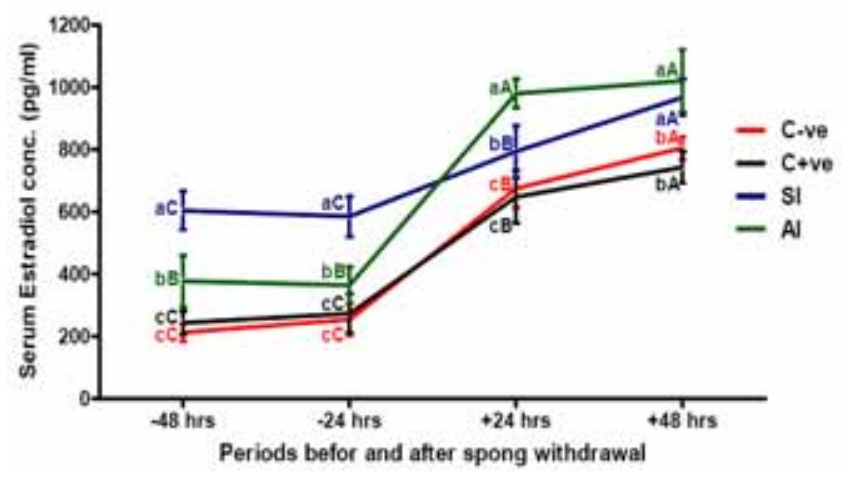

Figure 5: Serum Estradiol concentration $(\mathrm{pg} / \mathrm{ml})$ before 48 and $24 \mathrm{hrs}$. (A and B) and after 24 and $48 \mathrm{hr}$. (C and D) sponge withdrawal (at day 50 of treatment) in Awassi ewes injected, at 0,28 , and 50 days of treatment, 4,2 and $2 \mathrm{ml}$ of normal saline (control; C-ve), 400, 200 and $200 \mu \mathrm{g}$ of ovalbumine (positive control; C+ve), 400, 200 and $200 \mu \mathrm{g}$ of synthetic inhibin (SI group), and $4 \mathrm{ml}$ of normal saline followed by 4 and $2 \mathrm{ml}$ of SFBFF antiserum (AI group). The values represented as $\mathrm{M} \pm \mathrm{SD}$. Different small letters denote significant difference $(\mathrm{p}<0.05)$ between groups for each period. Different capital letters denote significant difference $(p<0.05)$ between periods for each group.

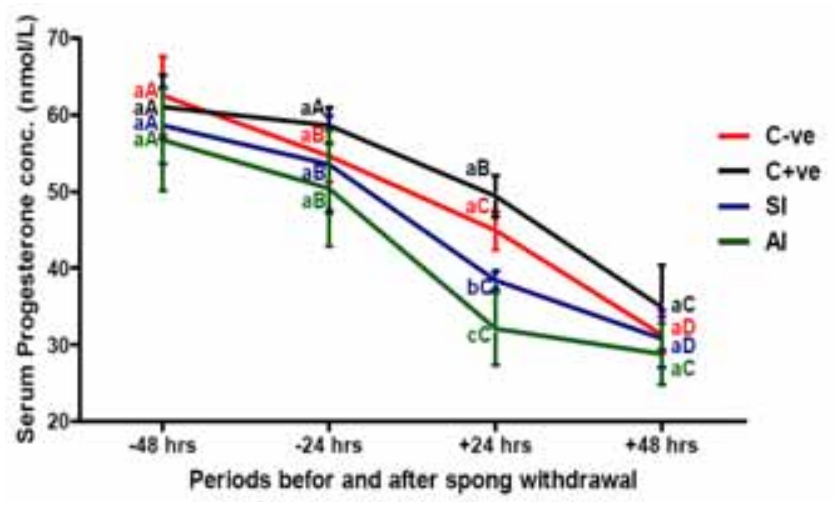

Figure 6: Serum Progesterone concentration (nmol/L) before 48 and $24 \mathrm{hrs}$. (A and B) and after 24 and $48 \mathrm{hr}$. (C and D) sponge withdrawal (at day 50 of treatment) in Awassi ewes injected, at 0, 28, and 50 days of treatment, 4, 2 and $2 \mathrm{ml}$ of normal saline (control; C-ve), 400, 200 and $200 \mu \mathrm{g}$ of ovalbumine (positive control; $\mathrm{C}+\mathrm{ve}$ ), 400, 200 and $200 \mu \mathrm{g}$ of synthetic inhibin (SI group), and $4 \mathrm{ml}$ of normal saline followed by 4 and $2 \mathrm{ml}$ of SFBFF antiserum (AI group). The values represented as $\mathrm{M} \pm \mathrm{SD}$. Different small letters denote significant difference $(p<0.05)$ between groups for each period. Different capital letters denote significant difference $(p<0.05)$ between periods for each group.

\section{Discussion}

The present study pointed out that active and passive immunization against endogenous inhibin has potent role on reproductive hormone concentrations during the periods before and after sponge withdrawal in Awassi ewes. The decline of inhibin-B concentrations in active (SI) and passive (AI) immunized group ewes could be due to the immunoneutralization of endogenous inhibin subunits caused by generating of high level of the inhibin antibodies rapidly and steadily after booster immunizations $(5,9,21$ $25)$, whereas it tend to return to the normal levels during and after $48 \mathrm{hr}$ of sponge withdrawal.

In both active and passive immunization, the current study reported significant elevation of serum activin-A concentration, which may attributed to the sharp decline of inhibins, where inhibins and activins are functionally antagonistic to each other (26). The inhibitory effect of inhibin on pituitary gonadotrophs was suppressed due to the immunoneutralization and subsequent decline of inhibin levels, these events along with the stimulatory effect of activin-A levels could be the main cause for FSH surge secretion from pituitary gonadotrophs. Thus the decrease in the levels of inhibin B in SI and AI treatment group ewes could induce the synthesis and secretion of a large amount of endogenous FSH from adenohypophesial gonadotrophs through the endocrine and autocrine/paracrine action of activin at the level of gonadotrope and granulosa cells $(27,28)$. The autocrine/paracrine action of activin caused elevated FSH $\beta$ mRNA expression levels in the gonadotrophs of adenohypophesis leading to increased FSH biosynthesis and secretion (29).

Subsequent to the elevated secretion of FSH, ovarian follicular development could be increased, since FSH is the main stimulator of ovarian folliculogenesis (11). Follicular development is usually accompanied by granulose and theca cells proliferation. These changes are concomitant up regulation of the aromatase activity and subsequent increase in estradiol biosynthesis. This might explain the significant increase of serum estradiol concentration reported in the present study. The significant elevation of $\mathrm{LH}$ concentration after sponge withdrawal could be attributed to the elevated levels of estradiol through the positive feedback mechanism of estradiol on pituitary gonadotrophs $(30,31)$. On the other hand, the role of activin, as a neuroendocrine reproductive controller, may be also act to modulate the LH- $\beta$ biosynthesis and release which may be enhanced via modulation of LH- $\beta$ subunit and GnRH receptor mRNA expression in response to activin action, which increased in the present results $(32,33)$.

It can be concluded that the present elucidation change in reproductive hormones out of season breeding indicates a highly significant potency of both active and passive immunonutralization against endogenous inhibin in Awassi 
ewes, and could play an important role in future animal reproduction applications.

\section{References}

1. Jaber LS, Habre A, Rawda N, Abisaid M, Barbour EK, Hamadeh SK. The effect of water restriction on certain physiological parameters in Awassi sheep. Small Rumin Res. 2004;54:115-120.

2. Al-Thabhawee AH, Samaka HM, Kadhim HM. Detection of (FecB) gene polymorphism in local sheep breed at different area of Iraq. Mirror of Research in Veterinary Sciences and animals. MRVSA, 2014;3(1):15-20.

3. Al-Khazraji AA, Abu-Tabeigh SM, Abdulkareem TA, Mahdi UA. Reproductive responses of Awassi ewes to different level of PMSG administration. Iraqi J Agric Sci. 2000;31:681-687.

4. Scaramuzzi RJ, Baird DT, Campbell BK, Driancourt MA, Dupont J, Fortune JE, Gilchrist RB, Martinm GB, McNattym KP, McNeilly AS, Monget P, Monniaux D, Viñoles C, Webb R. Regulation of folliculogenesis and the determination of ovulation rate in ruminants. Reprod Fertil Dev. 2010;23:444-67.

5. Al-Sa'aidi JAA, Al-Okaily BN, Al-Shwilly HA. Uterine Implantations and Litter Size Alteration in Anti-inhibin and eCG-hCG Treated Virgin Pregnant Female Rats. Online Int. Interdicip Res J. 2016;6(1):36-46.

6. Kishi H, Okada T, Otsuka M, Watanabe G, Taya K, Sasamoto S. Induction of superovulation by immunoneutralization of endogenous inhibin through the increase in the secretion of follicle-stimulating hormone in the cyclic golden hamster. J Endocrinol. 1996;151:65-75.

7. Wang H, Herath CB, Xia G, Watanabe G, Taya K. Superovulation, fertilization and in vitro embryo development in mice after administration of an inhibin neutralizing antiserum. Reprod. 2001;122:809-816.

8. Takedomi TH, Kaneko Y, Aoyagi K, Konishi H, Kishi Watanabe G, Taya K. Effects of passive immunization against inhibin on ovulation rate and embryo recovery in Holstein heifers. Theriogenol.1997;47:1507-1518.

9. Al-Sa'aidi JAA, Samir MS. Effect of passive immunization against inhibin subunit on ovarian growth and development in immature female Wister rats. $14^{\text {th }}$ Scientific Congress of Fac. Med., Assiut Univ. Egypt, 2010.

10. Wrathall JHM, McLeod BJ, Glencross RG, Beard AJ, Knight PG. Effects of active immunization against a synthetic peptide sequence of the inhibin $\alpha$-subunit on plasma gonadotrophin concentrations, ovulation rate and lambing rate in ewes. J Reprod Fertil. 1992;95:175182.

11. Rozell TG, Okrainetz RJ. FSH: One Hormone with Multiple Forms, or a Family of Multiple Hormones (Chapter 14). In Reproductive Endocrinology: A Molecular Approach. By Chedrese, PJ (Editor), 2009, Springer, New York, USA.

12. Goel AK, Agrawal KP. Ovulatory response and embryo yield in Jakhrana goats following treatments with PMSG and FSH. Trop Anim Health Prod. 2005;37:549-558.

13. Menchaca A, Vilarino M, Crispo M, Pinczak A, Rubianes E. Day 0 Protocol: Superstimulatory treatment initiated in the absence of a large follicle improves ovarian response and embryo yield in goats. Theriogenol. 2007;68(8):1111-1117.

14. Ertzeid G, Storeng R, Lyberg T. Treatment with gonadotropins impaired implantation and fetal development in mice. J Assist Reprod Genet. 1993;10:286-291.

15. D’Alessandro A, Martemucci G, Laffaldano N. Active immunization with a synthetic fragment of pig inhibin $\alpha$-subunit increases ovulation rate and embryo production in superovulated ewes but season affects its efficiency. J Reprod Fertil. 1999; 115:185-91.
16. Naqvi SMK, Joshi A, Gulyani R, Maurya VP, Manik, RS, Palta P. Active immunization against inhibin-based peptides to increase ovulation rate in non-prolific Malpura ewes. Small Rum Res. 2009;81:163-166.

17. Bleach ECL, Muttukrishna S, Cunningham FJ, Knight PG, Glencross RG. Effect of inhibin immunization using different synthetic peptide fragments of the bovine $\alpha$-subunit on plasma FSH concentrations and the incidence of multiple ovulations in heifers. Anim Reprod Sci. 1996;41:1-12.

18. Padilla G, Knight PG, Holtz W. Superovulation and embryo collection in nulliparous Boer goat does immunized against a recombinant ovine a-subunit inhibin. Small Rumin Res. 2008;74:159-64.

19. Al-Sa'aidi JAA, Majhwol EM. Effect of immunization against steroidfree bovine follicular fluid on reproductive hormones profile in cycling female rats. Asian J Anim Sci. 2017;11:183-188.

20. Shiefler W C. Statistics for Biological Sciences. 2nd Edn., Addison, Wesley Publ. Co., California, London. 1980.

21. Medan MS, Akagi S, Kaneko H, Watanabe G, Tsonis CG, Taya K. Effects of re-immunization of heifers against inhibition on hormonal profiles and ovulation rate. Reprod. 2004;128:475-482.

22. Al-Sa'aidi JAA, Baqir SM. Hypothalamic $G H R H$ and pituitary $G H$ genes expression levels in neonatal inhibin-immunoneutralized female rats. Aspire, The $5^{\text {th }}$ Congress of the Asia Pacific Initiative on Reproduction, 4-6 April 2014, Brisbane, Australia, FC 016, pp: 64.

23. Al-Sa'aidi JAA, Al-Kalby JMA, Al-Saeedi MJA. Effect of passive immunization against inhibin-A, -BA and -BB subunits on serum growth and differentiation hormones profile in pregnant and lactating primiparous Wister rats. Bas J Vet Res.2015;14(1):79-96.

24. Al-Sa'aidi JAA, Al-Asadi SHJ. Quantification of mammary Gh-r gene and $\mathrm{GH}$ expression in pregnant, delivered and lactating Wister female rats passively immunized at pregnancy against inhibin- $\alpha, \beta \mathrm{a}$, or $\beta \mathrm{b}$ subunits. Int J Biol Pharm Allied Sci. 2016; 5(9):2070-2083.

25. Al-Sa'aidi JAA, Al-Jayashi G. Adenohypophyseal Immunohistochemoial Expression Levels of FSH $\beta$ in Cyclic Virgin Female Rats Treated with Steroid Free Bovine Follicular Fluid Antiserum. Online Int. Interdicip Res J. 2016; VI, Issue-VI: 18-31.

26. Miyazono K, Kamiya Y, Morikawa M. Bone morphogenetic protein receptors and signal transduction. J Biochem. 2010;147:35-51.

27. Baratta M, West LA, Turzillo AM, Nett TM. Activin Modulates Differential Effects of Estradiol on Synthesis and Secretion of Follicle-Stimulating Hormone in Ovine Pituitary Cells. Biol Reprod. 2001;64:714-719.

28. Glister C, Tannetta DS, Groome NP, Knight PG. Interactions Between Follicle-Stimulating Hormone and Growth Factors in Modulating Secretion of Steroids and Inhibin-Related Peptides by Nonluteinized Bovine Granulosa Cells. Biol Reprod. 2001; 65:1020-1028.

29. Wang Y, Bernard DJ. Activin A induction of murine and ovine follicle-stimulating hormone $\beta$ transcription is SMAD-dependent and TAK1 (MAP3K7)/p38 MAPK-independent in gonadotrope-like cells. Cell. Signal. 2012;24(8):1632-1640.

30. Taya K, Watanabe G. Inhibin as a key hormone in determining species-specific ovulation rates in mammal. In: Kwon HB, Joss JMP, Ishii S. (eds.), Recent Progress in Molecular and Comparative Endocrinology. Kwangju, Korea: Hormone Research Center, Chonman National University, 1999;pp:134-143.

31. Taya K. Role of inhibin in regulation of FSH secretion and folliculogenesis in mammalians. Curr. Trends Exp Endocrinol. 1993;1:97-116.

32. Coss D, Thackray VG, Deng CX, Mellon PL. Activin regulates luteinizing hormone beta-subunit gene expression through Smadbinding and homeobox elements. Mol Endocrin. 2005;19:2610-2623.

33. Xia Y, Schneyer AL. Review: The biology of activin: recent advances in structure, regulation and function. J Endocrinol. 2009;202:1-12. 